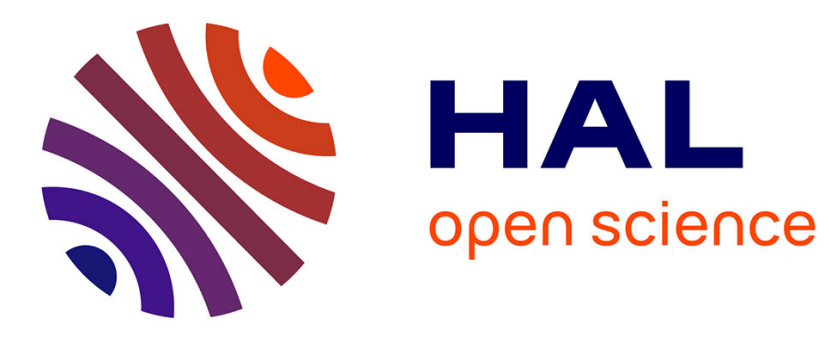

\title{
Waterworks Sludge: An Underrated Material for Beneficial Reuse in Water and Environmental Engineering
}

Yaqian Zhao, Ange Nzihou, Baiming Ren, Nathalie Lyczko, Cheng Shen, Chun Kang, Bin Ji

\section{To cite this version:}

Yaqian Zhao, Ange Nzihou, Baiming Ren, Nathalie Lyczko, Cheng Shen, et al.. Waterworks Sludge: An Underrated Material for Beneficial Reuse in Water and Environmental Engineering: review. Waste and Biomass Valorization, 2021, 12, pp.4239-4251. 10.1007/s12649-020-01232-w · hal-02948969

\section{HAL Id: hal-02948969 \\ https://imt-mines-albi.hal.science/hal-02948969}

Submitted on 22 Oct 2020

HAL is a multi-disciplinary open access archive for the deposit and dissemination of scientific research documents, whether they are published or not. The documents may come from teaching and research institutions in France or abroad, or from public or private research centers.
L'archive ouverte pluridisciplinaire HAL, est destinée au dépôt et à la diffusion de documents scientifiques de niveau recherche, publiés ou non, émanant des établissements d'enseignement et de recherche français ou étrangers, des laboratoires publics ou privés. 


\title{
Waterworks Sludge: An Underrated Material for Beneficial Reuse in Water and Environmental Engineering
}

\author{
Yaqian Zhao ${ }^{1}$ - Ange Nzihou ${ }^{2} \cdot$ Baiming Ren $^{2,3} \cdot$ Nathalie Lyczko ${ }^{2} \cdot$ Cheng Shen ${ }^{3} \cdot$ Chun Kang $^{1} \cdot$ Bin Ji $^{1}$
}

\begin{abstract}
Waterworks sludge refers to the inevitable suspended and dissolved solids produced during the water purification process when producing tap water where Al-salt and/or Fe-salt are used as coagulant worldwide. Waterworks sludge is dewatered and the resultant cakes have been treated as "waste" for landfill as their major final disposal solution for a long time in practice. As waterworks sludge is the residual of potable water treatment process, it is not harmful and without toxic elements such as heavy metals in most cases in comparison to sewage sludges for instance. Actually, waterworks sludge is an underrated material with huge potential for beneficial reuse as raw material in water and environmental engineering. However, little was significantly progressed on this topic until the last two decades. Research and development (R\&D) with special interest and focus on waterworks sludge reuse was conducted in our group in the last 15 years and this paper reports and discusses the main work and its novel application profile. Overall, it is believed that the R\&D of waterworks sludge is useful and will help to develop national strategy of the entire waterworks sludge management, allowing its transformation from a "waste" into value-added products, and thus contribute to sustainable development.
\end{abstract}

\section{Graphic Abstract}

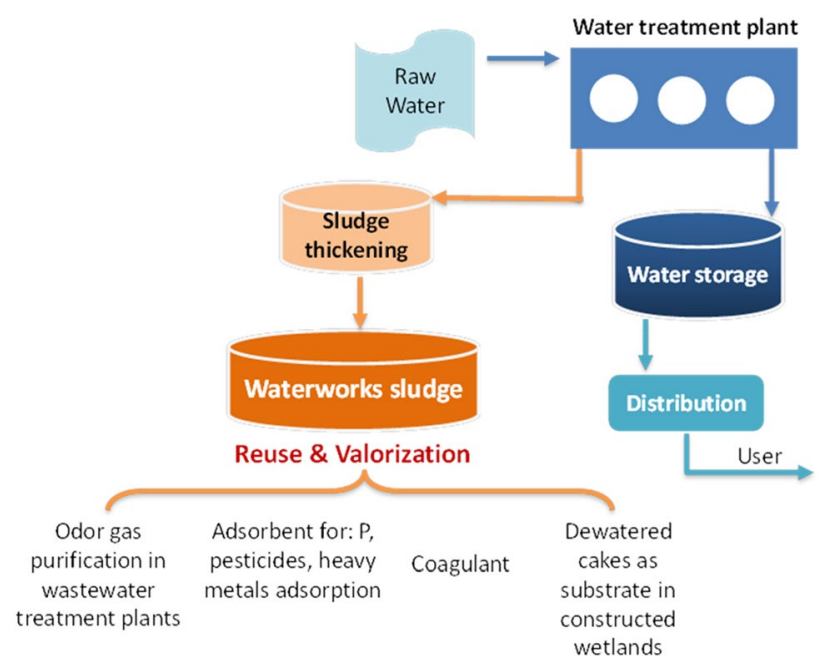

Keywords Adsorption $\cdot$ Waterworks sludge $\cdot$ Phosphorus $\cdot$ Reuse $\cdot$ Waste disposal

Yaqian Zhao

yaqian.zhao@ucd.ie

$\triangle$ Ange Nzihou

ange.nzihou@mines-albi.fr

\section{Statement of Novelty}

Water treatment sludge (WTS) has been an underrated material for a long time. It is generated during the water purification process with coagulant (Al- or/and Fe-salt) 
residuals while being without toxic elements and heavy metals. Indeed, it harbours huge potential in beneficial reuse as a raw material in water and environmental engineering. This paper outlines and assesses several novel reuse strategies developed in our group for promoting WTS reuse in wastewater and sewage sludge treatment processes. These include reuse as a low-cost adsorbent; as a main substrate in constructed wetlands; as a primary coagulant for high strength wastewater treatment; as a conditioner for co-conditioning/ dewatering with sewage sludge; and as a novel material for $\mathrm{H}_{2} \mathrm{~S} /$ odor gas purification, thus turning it from a "waste" into value-added products and contribute to sustainable development.

\section{Introduction}

Water is essential for life and purification of raw/source water into drinking water requires the addition of chemical(s) to enhance the efficiency. Such chemicals are called coagulants while the various impurities in raw/source water together with the coagulant residue will generate inevitable by-products in the form of water treatment sludge (WTS). Alum and/or Ferric salts are commonly used coagulants. Accordingly, "alum sludge (AIS)" is generated when alum salt is used in waterworks for the purification process [1]. As the volume of AlS increased worldwide due to the increasing demand for clean water with the rapid escalation of world population and urban expansion, a significant concern on how to effectively and efficiently manage AlS was raised with the aim to achieve economical savings of disposal and maintain the environment sustainably. Indeed, there have been an increasing number of studies worldwide in the last two decades to develop various beneficial reuse strategies of WTS in water and environmental engineering. The driving force behind this lies in the fact that WTS is relatively clean without harmful and toxic elements in most cases [2-4].

A useful tool for relevant literature search and analysis is bibliometric analysis. It can be applied to identify and link key aspects of a certain subject. The performed bibliometric mapping allowed the identification of the most cited items in literature and the investigation of relationships between the terms obtained. As such, a search at the "Web of Science" database using the keywords of 'waterworks sludge' OR 'waterworks residue' OR 'alum sludge' OR 'water treatment plant sludge' OR 'drinking water sludge' was performed and 440 publications, in scientific journals from 2000 to April of 2020, were obtained (Fig. 1). In spite of the relatively limited papers in the last 20 years, Fig. 1 does give us a profile of the current status of WTS studies. The increased number of studies will bring the R\&D of WTS to a high level towards various reuse routes and final sustainable disposal. By using VOSviewer software to analyze the keywords of the papers

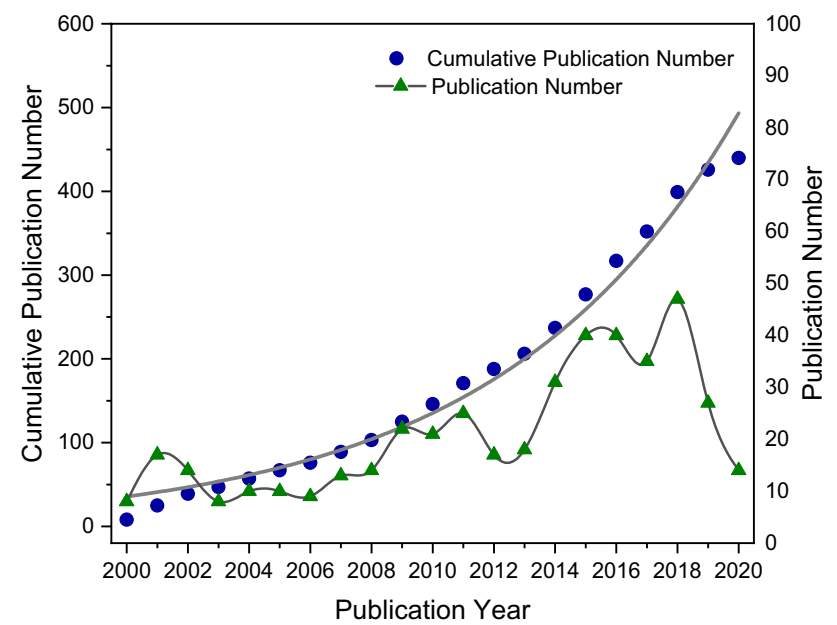

Fig. 1 Publications of WTS studies in the last 20 years based on Web of Science search

regarding WTS studies in the literature, the bibliometricmapping of keyword density visualization was obtained (Fig. 2). The red areas in Fig. 2 represent hotspots. From this map, we can see that considerable attention has been paid to WTS reuse and multiple applications. Among these, the AlS reuse as a substrate in constructed wetlands (CWs) has been intensively identified.

Intensive research and development (R\&D) was conducted in our group in the last 15 years with a special interest and focus on WTS, especially AIS and various beneficial reuse, and this paper reports the main work and the updated novel application profile.

\section{Production and Characteristics of Waterworks Sludge}

Conventional waterworks involves the processes of coagulation \& flocculation, sedimentation, filtration and disinfection with a large quantity of sludge generated as inevitable byproducts during the sedimentation process (after coagulation $\&$ flocculation) and the back washing process during the filtration stage [5]. These two streams of sludges will be subject to thickening and conditioning before dewatering to result in the cakes for final disposal (Fig. 3). It has been normally estimated that WTS production from waterworks comprises $1-3 \%$ of the total volume of raw water used during the treatment process [6]. It is difficult to obtain accurate data on overall WTS generation at the global level but WTS generation in China is the highest globally at 2.3 million tonnes per year. However, the largest quantity of annual WTS generation per person is in Korea. By contrast, Denmark generates the least WTS at 10,000 tons/year as well as the least quantity of annual WTSs generation per person. 
Fig. 2 Bibliometric map generated based on density visualization from VOSViewer-red areas represent hotspots. (Color figure online)
Fig. 3 Overview of waterworks sludge generation in water treatment process
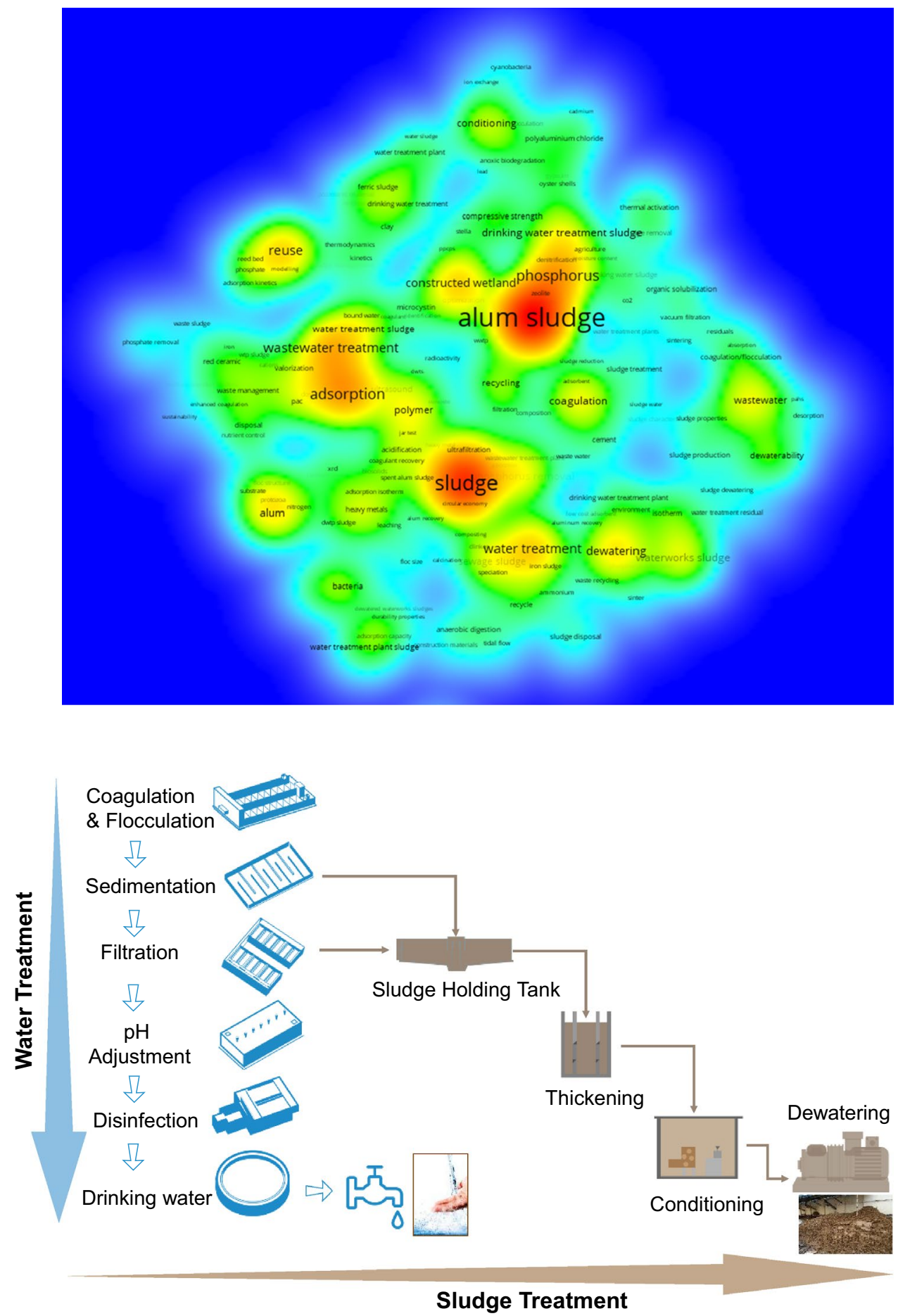

The sludge disposal cost in Netherlands stands at a huge sum of US\$37-50 million per year while it is \$6.2 million per year in Australia. It is also estimated that the cost of WTS disposal in Ireland will be doubled by the end of the next decade from the present assessment of 15,000-18,000 tons/ year of the dried solids [7-10].

With regard to the nature of WTS, it is produced with various impurities and contaminants such as clay minerals, sandy and loamy particles, organic matter, microorganisms, and trace heavy metals etc. depending on the source waters. These particles are agglomerated with the residual of dosed Al or Fe salts. Obviously, the amount of WTS depends on the quality of raw water treated and the efficiency of operational units involved in the water treatment processes. It should be noted that WTS is generally clean without toxic elements since the water resource areas are 
normally protected to ensure the quality of raw water away from potential pollution.

The physicochemical characteristics of WTS vary according to a number of factors of the quality of raw water, nature of coagulants used, treatment technology involved and the final quality of water produced. In general, $\mathrm{SiO}_{2}$ constitutes the majority of the sludge followed by $\mathrm{Al}_{2} \mathrm{O}_{3}$ and $\mathrm{Fe}_{2} \mathrm{O}_{3}$; other oxides such as $\mathrm{CaO}, \mathrm{MgO}, \mathrm{Na}_{2} \mathrm{O}, \mathrm{K}_{2} \mathrm{O}, \mathrm{P}_{2} \mathrm{O}_{5}$ and $\mathrm{TiO}_{2}$ are also found in small percentages. The amount of $\mathrm{Al}_{2} \mathrm{O}_{3}$ or $\mathrm{Fe}_{2} \mathrm{O}_{3}$ in WTS is also associated with the coagulant applied (Al or Fe salts) and the concentration of these metals in the raw water. From the literature, physicochemical composition of Al-based and Fe-based WTS is summarized in Table 1. It is reasonable to understand that the composition of WTS varies but $\mathrm{Al}$ and Fe are of course the major elements. Some heavy metals are also reported in WTS analyses. They are also an indication of source water quality or pollution although they were concentrated into WTS during the treatment processes.

\section{WTS Used as Low-cost Adsorbent for Various Pollutant Immobilization}

Reuse of dewatered WTS as low-cost adsorbent for phosphorus $(\mathrm{P})$ immobilization represents a large number of investigations in the past $[1,3,17,18]$. Intensive studies have been conducted to explore the capacity of reusing dewatered WTS for various $\mathrm{P}$ and pesticide adsorption [6, 19-21]. Static adsorption tests and column trials were conducted and adsorption behaviour had been investigated in great detail across the world. It has been well demonstrated that WTS have a strong affinity with $\mathrm{P}$ while Ligand-exchange is the dominant mechanism based on exploratory evidence from the adsorption mechanism of P onto the AlS. Although chemical reaction between phosphate and dissolved aluminium was demonstrated, it is believed that the chemical reaction plays only a marginal role in the phosphate removal process [22]. The maximum $\mathrm{P}$ adsorption capacity by AlS can be seen from Table 2 . It should be noted that the P adsorption capacity may be linked with the experimental conditions, while caution should be paid when comparing it between different studies. In addition, Zhao et al., [23] reported that the AlS has considerable ability for arsenic immobilization, while Shakya et al. [8] investigated practical approach on reuse of drinking water treatment plant residuals for fluoride removal. Adsorption behaviours of AlS for arsenic adsorption were investigated and the results had shown that the maximum adsorption capacities ranged from 0.61 to $0.96 \mathrm{mg} \mathrm{As} / \mathrm{g}$ when the $\mathrm{pH}$ of the arsenic solution was varied from 9.0 to 4.0 [23]. WTR has been demonstrated to own a good ability for fluoride removal in contaminated groundwater from initial $5.0 \mathrm{mg} / \mathrm{L}$ to about $90 \%$ reduction within $2 \mathrm{~h}$ contact time at WTR dose of $28 \mathrm{~g} / \mathrm{L}$ in the $\mathrm{pH}$ range of 5-8 to meet the drinking water standard [8].

To further expand the scope of reuse, WTS have been tested for a number of heavy metals and semimetals adsorption in studies of varied scale which include $\mathrm{Cd}, \mathrm{Cr}, \mathrm{Co}$, $\mathrm{Cu}, \mathrm{Pb}, \mathrm{Hg}, \mathrm{Ni}, \mathrm{Zn}, \mathrm{Mo}, \mathrm{V}, \mathrm{Ga}$, As, Se, and B (Fig. 4). Shen et al., [4] conducted a comprehensive review on this aspect
Table 1 Physicochemical composition of AlS and Fe-WTS [3]

\begin{tabular}{lllll}
\hline Parameter & Units & Al-sludge & Fe-sludge & References \\
\hline $\mathrm{pH}$ & & $6.5 \pm 0.3^{\mathrm{a}}$ & $7.0 \pm 1.3$ & Inputs from \\
$\mathrm{Total}$ solids & $\mathrm{mg} / \mathrm{L}$ & $2500-52,345$ & $2132-5074$ & {$[1,4,11-16]$} \\
$\mathrm{Al}$ & $\mathrm{mg} / \mathrm{kg}$ & $118,700 \pm 24,260$ & $61,390 \pm 35,920$ & \\
$\mathrm{Fe}$ & $\mathrm{mg} / \mathrm{kg}$ & $37,000 \pm 19,740$ & $220,900 \pm 32,200$ & \\
$\mathrm{Ca}$ & $\mathrm{mg} / \mathrm{kg}$ & $10,360 \pm 4299$ & $\mathrm{Nd}$ & \\
$\mathrm{Mg}$ & $\mathrm{mg} / \mathrm{kg}$ & $2407 \pm 572$ & $\mathrm{Nd}$ & \\
$\mathrm{Na}$ & $\mathrm{mg} / \mathrm{kg}$ & $355 \pm 142$ & $\mathrm{Nd}$ & \\
$\mathrm{K}$ & $\mathrm{mg} / \mathrm{kg}$ & $3547 \pm 582$ & $\mathrm{Nd}$ & \\
$\mathrm{S}$ & $\mathrm{mg} / \mathrm{kg}$ & $6763 \pm 2955$ & $\mathrm{Nd}$ & \\
$\mathrm{Mn}$ & $\mathrm{mg} / \mathrm{kg}$ & $2998 \pm 1122$ & $1088 \pm 178$ & \\
$\mathrm{Zn}$ & $\mathrm{mg} / \mathrm{kg}$ & $98 \pm 31$ & $36 \pm 4$ & \\
$\mathrm{Cu}$ & $\mathrm{mg} / \mathrm{kg}$ & $624 \pm 581$ & $46 \pm 12$ & \\
$\mathrm{Ni}$ & $\mathrm{mg} / \mathrm{kg}$ & $28 \pm 10$ & $64 \pm 14$ & \\
$\mathrm{~Pb}$ & $\mathrm{mg} / \mathrm{kg}$ & $22 \pm 12$ & $47 \pm 1$ & \\
$\mathrm{Cr}$ & $\mathrm{mg} / \mathrm{kg}$ & $20 \pm 7$ & $38 \pm 4$ & \\
$\mathrm{Cd}$ & $\mathrm{mg} / \mathrm{kg}$ & $0.12 \pm 0.02$ & $\mathrm{Nd}$ & $\mathrm{Nd}$ \\
$\mathrm{Hg}$ & $\mathrm{mg} / \mathrm{kg}$ & 0.46 & & \\
\hline
\end{tabular}

$N d$ not determined

${ }^{a}$ Numbers are means \pm SD 
Table 2 Comparison of maximum P adsorption capacities by WTS [13]

\begin{tabular}{|c|c|c|c|}
\hline \multirow[t]{2}{*}{ Test conditions } & \multicolumn{3}{|c|}{ Maximum adsorption capacity $\mathrm{Q}_{0}\left(\mathrm{mg} \mathrm{PO}_{4}{ }^{3-} / \mathrm{g}\right.$ WTS $)$} \\
\hline & Ortho-P & Poly-P & Organic-P \\
\hline $\begin{array}{l}\text { Particle size }<2.36 \mathrm{~mm} \\
\text { pH } 4.0 \\
\text { Equilibration time } 1 \text { day }\end{array}$ & $\begin{array}{l}10.2 \\
\text { (Initial P concentration } 14.7 \mathrm{mg} \\
\mathrm{PO}_{4}{ }^{3-} / \mathrm{L} \text { ) }\end{array}$ & $\begin{array}{l}7.4 \\
\text { (Initial } \mathrm{P} \text { concentration } \\
\left.10.8 \mathrm{mg} \mathrm{PO}_{4}{ }^{3-} / \mathrm{L}\right)\end{array}$ & $\begin{array}{l}4.8 \\
\text { (Initial P concen- } \\
\text { tration } 3.3 \mathrm{mg} \\
\mathrm{PO}_{4}{ }^{3-} / \mathrm{L} \text { ) }\end{array}$ \\
\hline $\begin{array}{l}\text { Particle size }<2 \mathrm{~mm} \\
\text { Initial P concentration up to } 4000 \mathrm{mg} \mathrm{PO}_{4}{ }^{3-} / \mathrm{L} \text {; } \\
\text { pH 7.1 } \\
\text { Equilibration time overnight }\end{array}$ & 25.0 & 14.3 & 12.5 \\
\hline $\begin{array}{l}\text { Particle size } 0.063-2.36 \mathrm{~mm} \\
\text { Initial P concentration } 15.3 \mathrm{mg} \mathrm{PO}_{4}{ }^{3-} / \mathrm{L} \\
\mathrm{pH} 4.3\end{array}$ & 10.5 & - & - \\
\hline Not specified & $0.30-0.33$ & - & - \\
\hline $\begin{array}{l}\text { Particle size } 0.1-0.3 \mathrm{~mm} \\
\text { Initial P concentration } 918 \mathrm{mg} \mathrm{PO}_{4}{ }^{3-} / \mathrm{L} \\
\text { Equilibration time } 1 \text { day }\end{array}$ & 38.3 & - & - \\
\hline $\begin{array}{l}\text { Particle size }<2 \mathrm{~mm} \\
\text { Initial P concentration } 10.7 \mathrm{~g} \mathrm{PO}_{4}^{3-} / \mathrm{L} \\
\text { Equilibration time } 17 \mathrm{~h}\end{array}$ & $2.02-50.49$ & - & - \\
\hline $\begin{array}{l}\text { Particle size }<150 \mu \mathrm{m} \\
\text { Initial P concentration } 0-10.7 \mathrm{~g} \mathrm{PO}_{4}{ }^{3-} / \mathrm{L}\end{array}$ & $\begin{array}{l}5.63-90.27 \\
\text { (Equilibration time } 17 \mathrm{~h} \text { ) } \\
31.82-113.22 \\
\text { (Equilibration time } 6 \text { days) }\end{array}$ & - & - \\
\hline $\begin{array}{l}\text { Particle size }<2 \mathrm{~mm} \\
\text { Initial P loading } 30.6 \mathrm{mg} \mathrm{PO}_{4}{ }^{3-} / \mathrm{g} \text { sludge } \\
\text { Equilibration time } 10 \text { days }\end{array}$ & $\begin{array}{l}22.95-30.60 \\
\text { (four kinds of AlS tested) }\end{array}$ & - & - \\
\hline
\end{tabular}

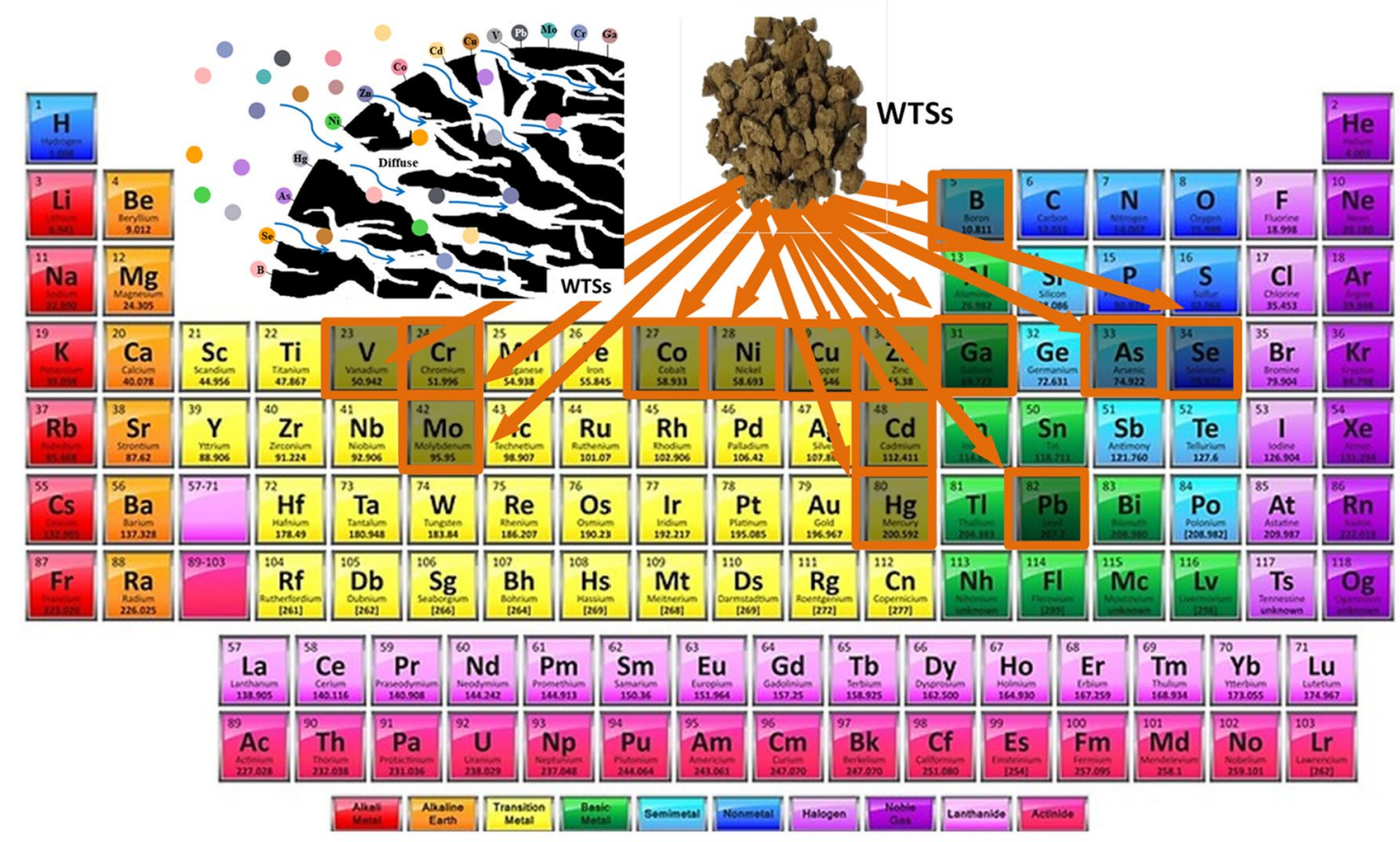

Periodic table of the elements

Fig. 4 Overview of WTS adsorption of various heavy metals and semimetals 
and adsorption capacities are reported in Table 3. These studies have approved the effectiveness of WTS to be a considerable low-cost adsorbent for a wide range of pollutant removal in wastewaters, thus turning WTS from "waste" for landfilling into useful materials for water and environmental engineering practice.

In recent years, to better use WTS as adsorbent, granulations of WTS have been increasingly studied. Granulation is a technique of particle enlargement by agglomeration; it is one of the most significant and commonly used operations in the production of pellet/granular forms [24]. During the granulation process, fine or coarse particles of WTS are converted into large agglomerates [25]. These pellet type WTRs are easy to separate and recover from the adsorption process and more suitable to be used in wastewater treatment facilities such as columns, beds and filters due to the increased compressive strength and hydraulic conductivity $[26,27]$. Therefore, WTR granulation could widen WTR reuse routes and also seems to be a promising strategy to promote large engineering application of WTS. The current approaches of granulation methodologies are classified in three broad categories: sintering WTS ceramsite [28, 29], gel entrapment [30] and newly emerged techniques e.g., freeze-thaw process [31] and natural curing [32]. No doubt, these efforts have successfully demonstrated the potential of WTS as novel value-added products.

\section{WTS Used as Substrate in Developing Constructed Wetland Treatment Systems}

Use of dewatered WTS as the main wetland substrate to develop the new generation of constructed wetlands (CW) for wastewater treatment represents a great showcase of the beneficial reuse of WTS $[33,34]$. Great efforts have been made on AlS-based CW development with novel operation strategies of "tidal flow" and "intermittent aeration" allowing the CW to treat high strength wastewater $[33,35,36]$.

$\mathrm{CW}$ has risen in popularity and has been widely applied at the global level for various wastewater treatment applications due to its good treatment efficiency, low cost of operation and maintenance, and aesthetic value [37, 38]. However, it is important to note that $\mathrm{CW}$ is a biofilm-based wastewater treatment technology. The soul of the $\mathrm{CW}$ lies in the biofilm developed on its substrate with microorganism activities being the main drivers for wastewater biogradation/purification [39]. Meanwhile, CW is also a biofilter-like wastewater treatment facility i.e. substrate/ filter medium plays a very important role. Developing new materials with $\mathrm{P}$ and other pollutants is the priority in $\mathrm{CW}$ development. WTS in the form of dewatered AlS was first tested as a wetland substrate in 2008 [40] and dewatered AlS has been examined as good material in CW system with the following properties: (1) as carrier for biofilm development; (2) as low-cost adsorbent for pollutant ( $\mathrm{P}$ and others) immobilization; and (3) as growing medium to support wetland plant growth [41].

Thereafter, field pilot-scale trials of an AlS-based four-stage $\mathrm{CW}$ system were conducted for high strength farmyard wastewater treatment. The study showed excellent pollutant removal efficiencies with mean monthly removal percentages of $\mathrm{BOD}_{5}, \mathrm{COD}$, total nitrogen (TN), ammoniacal nitrogen $\left(\mathrm{NH}_{4}-\mathrm{N}\right)$, total phosphorus (TP), IP (inorganic phosphorus) and SS in the range of 57-84\%, 36-84\%, 11-78\%, 49-93\%, 75-94\%, 73-97\% and 46-83\%, respectively (Fig. 5) [39].

In recent years, the AlS-based wetland system has been further studied by embedding it into the traditional main wastewater treatment process (i.e. activated sludge process) to develop a so-called "Green-Bio-sorption Reactor" (GBR) [42]. It has been well demonstrated that the involvement of $\mathrm{CW}$ in the activated sludge process could achieve ' $1+1>2$ ' regarding enhanced treatment efficiency and upgrading the activated sludge process with aesthetic value (Fig. 6a) [43]. Insight into the pollutant removal potential, particularly the role of the AlS-based CW in the GBR, showed that the GBR achieved $91.2 \%$ and $94.8 \%$ removal for TN and TP respectively under hydraulic and nitrogen loading rates of $2.07 \mathrm{~m}^{3} /\left(\mathrm{m}^{3}\right.$ day $)$ and $166.2 \mathrm{~g} \mathrm{~N} /$ $\left(\mathrm{m}^{3}\right.$ day) respectively. The AlS-based $\mathrm{CW}$ revealed dualintensification in both capacity and efficiency [43]. Most recently, floating wetland has been well studied to further use the AlS as media to enhance floating wetland wastewater treatment efficiency (Fig. 6b) [44].

In addition, the AlS-based wetland system has been integrated with microbial fuel cell (MFC) to further expand its scope to develop the MFC-CW system to simultaneously achieve the dual goals of wastewater treatment and bioelectricity generation [45-49]. Indeed, the embedding of MFC into AlS-based CW represented a great development in $\mathrm{CW}$ system in recent years. Although this novel technical is still in its infant developing stage, it is clear that compared with conventional $\mathrm{CW}$, it is important to state that MFC-CW can improve wastewater treatment efficiency by the inner MFC function. Xu et al. [47] found $\mathrm{NH}_{4}-\mathrm{N}$ removal efficiency was increased from $44.63 \pm 2.07 \%$ to $81.10 \pm 2.07 \%$ in a multiple-cathode MFC-CW. More importantly, the generated electricity, although it is minor, can develop the biosensor, which owns a promising feature in the future to realise online $\mathrm{CW}$ operation management. 
Table 3 WTSs used as heavy metals and semimetals adsorption from aqueous environment [4]

\begin{tabular}{|c|c|c|}
\hline Plant & Type of sludge & Adsorption capacity \\
\hline Sassari, Italy & AlS & $12.873 \mathrm{mg} \mathrm{Pb}(\mathrm{II}) / \mathrm{g}, 3.494 \mathrm{mg} \mathrm{Cu}(\mathrm{II}) / \mathrm{g}, 4.48 \mathrm{mg} \mathrm{Cd}(\mathrm{II}) / \mathrm{g}, 3.250 \mathrm{mg} \mathrm{Zn(II)/g}$ \\
\hline Bidifhinzu, Italy & Fe-WTS & $12.873 \mathrm{mg} \mathrm{Pb}(\mathrm{II}) / \mathrm{g}, 3.496 \mathrm{mg} \mathrm{Cu}(\mathrm{II}) / \mathrm{g}, 7.28 \mathrm{mg} \mathrm{Cd}(\mathrm{II}) / \mathrm{g}, 5.252 \mathrm{mg} \mathrm{Zn(II)/g}$ \\
\hline Sassari, Italy & AlS & 30.4-94 mg As/g \\
\hline Sassari, Italy & Fe-WTS & $75-139 \mathrm{mg} \mathrm{As} / \mathrm{g}$ \\
\hline Flandria, Belgium & Fe-WTS & $40.0 \mathrm{mg} \mathrm{As}(\mathrm{V}) / \mathrm{g}, 119.97 \mathrm{mg} \mathrm{Pb}(\mathrm{II}) / \mathrm{g}, 21.02 \mathrm{mg} \mathrm{Cd}(\mathrm{II}) / \mathrm{g}, 40.01 \mathrm{mg} \mathrm{Zn}(\mathrm{II}) / \mathrm{g}$ \\
\hline \multirow[t]{2}{*}{ Tempa, USA } & Fe-WTS & $>10 \mathrm{mg} \mathrm{As}(\mathrm{V}) / \mathrm{g},>14 \mathrm{mg} \mathrm{As}(\mathrm{III}) / \mathrm{g}$ \\
\hline & Fe-WTS & $6.52-11.21 \mathrm{mg}$ As(III)/g, 4.92-9.18 mg As(V)/g \\
\hline \multirow[t]{3}{*}{ Bradenton, USA } & AlS & $79 \mathrm{mg} \mathrm{Hg}(\mathrm{II}) / \mathrm{g}$ \\
\hline & AlS & $>15 \mathrm{mg} \mathrm{As}(\mathrm{V}) / \mathrm{g},>8 \mathrm{mg}$ As $(\mathrm{III}) / \mathrm{g}$ \\
\hline & AlS & 34.4-40.24 mg As(III)/g, 44.95-49.98 mg As (V)/g \\
\hline Fort colins,USA & Als & 1.4-2.1 mg Se(VI)/g, 1.4-1.95 mg Se(IV)/g \\
\hline Michagan, USA & AlS & $10 \mathrm{mg} \mathrm{Cu}(\mathrm{II}) / \mathrm{g}$ \\
\hline Colorado, USA & Fe-WTS & $>0.113 \mathrm{mg} \mathrm{B}(\mathrm{III}) / \mathrm{g},>0.023 \mathrm{mg} \mathrm{Cr}(\mathrm{VI}) / \mathrm{g}, 0.038 \mathrm{mg} \mathrm{Se}(\mathrm{VI}) / \mathrm{g},>0.3 \mathrm{mg} \mathrm{Cu}(\mathrm{II}) / \mathrm{g},>0.0071 \mathrm{mg} \mathrm{Pb}(\mathrm{II}) / \mathrm{g}$ \\
\hline Brandon, USA & Fe-WTS & $2.23 \mathrm{mg} \mathrm{As} / \mathrm{g}$ \\
\hline Texas, USA & Fe-WTS & $0.029 \mathrm{mg} \mathrm{B}(\mathrm{III}) / \mathrm{g},>0.0066 \mathrm{mg} \mathrm{Cr}(\mathrm{VI}) / \mathrm{g},>0.00011 \mathrm{mg} \mathrm{Se}(\mathrm{VI}) / \mathrm{g},>0.320 \mathrm{mg} \mathrm{Cu}(\mathrm{II}) / \mathrm{g}$ \\
\hline New York, USA & Fe-WTS & $4.29 \mathrm{mg} \mathrm{As} / \mathrm{g}$ \\
\hline Tampa, USA & Fe-WTS & As \\
\hline Bradenton, USA & AlS & As \\
\hline Brisbane, Australia & AlS & $62.16 \mathrm{mg} \mathrm{Pb}(\mathrm{II}) / \mathrm{g}, 86.83 \mathrm{mg} \mathrm{Cr}(\mathrm{III}) / \mathrm{g}, 58.75 \mathrm{mg} \mathrm{Cr}(\mathrm{VI}) / \mathrm{g}, 20.98 \mathrm{mg} \mathrm{As}(\mathrm{V}) / \mathrm{g}, 18.73 \mathrm{mg} \mathrm{As}(\mathrm{III}) / \mathrm{g}$ \\
\hline Brisbane, Australia & AlS & $9.53 \mathrm{mg} \mathrm{Mo}(\mathrm{VI}) / \mathrm{g}, 13.02 \mathrm{mg} \mathrm{V}(\mathrm{V}) / \mathrm{g}, 17.36 \mathrm{As}(\mathrm{V}) / \mathrm{g}, 28.74 \mathrm{mg} \mathrm{Ga}(\mathrm{III}) / \mathrm{g}$ \\
\hline Dartmouth, Canada & AlS & $0.003 \mathrm{mg} \mathrm{As} / \mathrm{g}$ \\
\hline Brandon, Canada & Ca-WTS & $0.16 \mathrm{mg} \mathrm{As} / \mathrm{g}$ \\
\hline Kelantan, Malaysia & AlS & $\mathrm{Cu}(\mathrm{II}), \mathrm{Zn}(\mathrm{II})$ \\
\hline Johore, Malaysia & AlS & $10.638 \mathrm{mg} \mathrm{Cu}(\mathrm{II}) / \mathrm{g}$ \\
\hline Peiking, China & $\mathrm{Fe}(\mathrm{Al})-\mathrm{WTS}$ & $17.31 \mathrm{mg} \mathrm{Co}(\mathrm{II}) / \mathrm{g}$ \\
\hline Sivas, Turkey & Fe-WTS & $6.97 \mathrm{mg} \mathrm{Ni}(\mathrm{II}) / \mathrm{g}$ \\
\hline Mumbai, India & AlS & $\mathrm{Cu}(\mathrm{II}), \mathrm{Co}(\mathrm{II}), \mathrm{Cr}(\mathrm{VI}), \mathrm{Hg}$ (II), $\mathrm{Pb}$ (II), Zn(II) \\
\hline Miyamachi, Japan & AlS & $5.3 \mathrm{mg} \mathrm{Cd}(\mathrm{II}) / \mathrm{g}$ \\
\hline Nishino, Japan & $\mathrm{AlS}^{\mathrm{a}}$ & $9.2 \mathrm{mg} \mathrm{Cd}(\mathrm{II}) / \mathrm{g}$ \\
\hline Taiwan & $\mathrm{Fe}(\mathrm{Mn})-\mathrm{WTS}$ & $16.6 \mathrm{mg} \mathrm{Ni}(\mathrm{II}) / \mathrm{g}$ \\
\hline Taiwan & Als & $0.98 \mathrm{mg} \mathrm{B} / \mathrm{g}$ \\
\hline GU, UK & Als & $0.01-0.011 \mathrm{mg} \mathrm{Pb} / \mathrm{g}, 0.03-0.11 \mathrm{mg} \mathrm{Cr} / \mathrm{g}, 0.01-0.06 \mathrm{mg} \mathrm{Cd} / \mathrm{g}$ \\
\hline WD, UK & AlS & $0.01-0.02 \mathrm{mg} \mathrm{Pb} / \mathrm{g}, 0.1-0.14 \mathrm{mg} \mathrm{Cr} / \mathrm{g}, 0.1-0.66 \mathrm{mg} \mathrm{Cd} / \mathrm{g}$ \\
\hline OS, UK & AlS & $0.013-0.04 \mathrm{mg} \mathrm{Pb} / \mathrm{g}, 0.08-0.1 \mathrm{mg} \mathrm{Cr} / \mathrm{g}, 0.25-0.52 \mathrm{mg} \mathrm{Cd} / \mathrm{g}$ \\
\hline HU, UK & AlS & $0.014-0.02 \mathrm{mg} \mathrm{Pb} / \mathrm{g}, 0.08-0.11 \mathrm{mg} \mathrm{Cr} / \mathrm{g}, 0.01-0.02 \mathrm{mg} \mathrm{Cd} / \mathrm{g}$ \\
\hline WA, UK & AlS & $0.024-0.06 \mathrm{mg} \mathrm{Pb} / \mathrm{g}, 0.12-0.16 \mathrm{mg} \mathrm{Cr} / \mathrm{g}, 0.13-0.7 \mathrm{mg} \mathrm{Cd} / \mathrm{g}$ \\
\hline BS, UK & Fe-WTS & $0.01-0.02 \mathrm{mg} \mathrm{Pb} / \mathrm{g}, 0.07-0.1 \mathrm{mg} \mathrm{Cr} / \mathrm{g}, 0.02-0.07 \mathrm{mg} \mathrm{Cd} / \mathrm{g}$ \\
\hline MO, UK & Fe-WTS & $0.01-0.014 \mathrm{mg} \mathrm{Pb} / \mathrm{g}, 0.091 \mathrm{mg} \mathrm{Cr} / \mathrm{g}, 0.03-0.1 \mathrm{mg} \mathrm{Cd} / \mathrm{g}$ \\
\hline $\mathrm{HO}, \mathrm{UK}$ & Fe-WTS & $0.017-0.08 \mathrm{mg} \mathrm{Pb} / \mathrm{g}, 0.02-0.12 \mathrm{mg} \mathrm{Cr} / \mathrm{g}, 0.15-0.4 \mathrm{mg} \mathrm{Cd} / \mathrm{g}$ \\
\hline CA, UK & Fe-WTS & $0.027-0.04 \mathrm{mg} \mathrm{Pb} / \mathrm{g}, 0.08-0.11 \mathrm{mg} \mathrm{Cr} / \mathrm{g}, 0.08-0.17 \mathrm{mg} \mathrm{Cd} / \mathrm{g}$ \\
\hline FO, UK & Fe-WTS & $0.01-0.02 \mathrm{mg} \mathrm{Pb} / \mathrm{g}, 0.02-0.11 \mathrm{mg} \mathrm{Cr} / \mathrm{g}, 0.05-0.2 \mathrm{mg} \mathrm{Cd} / \mathrm{g}$ \\
\hline $\mathrm{HH}, \mathrm{UK}$ & Fe-WTS & $0.02-0.04 \mathrm{mg} \mathrm{Pb} / \mathrm{g}, 0.13 \mathrm{mg} \mathrm{Cr} / \mathrm{g}, 0.02-0.03 \mathrm{mg} \mathrm{Cd} / \mathrm{g}$ \\
\hline $\mathrm{AR}, \mathrm{UK}$ & Fe-WTS & $0.015-0.03 \mathrm{mg} \mathrm{Pb} / \mathrm{g}, 0.06-0.11 \mathrm{mg} \mathrm{Cr} / \mathrm{g}, 0.02-0.1 \mathrm{mg} \mathrm{Cd} / \mathrm{g}$ \\
\hline WY, UK & Fe-WTS & $0.013-0.02 \mathrm{mg} \mathrm{Pb} / \mathrm{g}, 0.11 \mathrm{mg} \mathrm{Cr} / \mathrm{g}, 0.01-0.45 \mathrm{mg} \mathrm{Cd} / \mathrm{g}$ \\
\hline BU, UK & Fe-WTS & $0.008-0.02 \mathrm{mg} \mathrm{Pb} / \mathrm{g}, 0.09-0.1 \mathrm{mg} \mathrm{Cr} / \mathrm{g}, 0.014-0.82 \mathrm{mg} \mathrm{Cd} / \mathrm{g}$ \\
\hline
\end{tabular}

${ }^{\mathrm{a}}$ WTS containing activated carbon introduced with coagulants 
Fig. 5 Field study of AlS-based $\mathrm{CW}$ for animal farm wastewater treatment

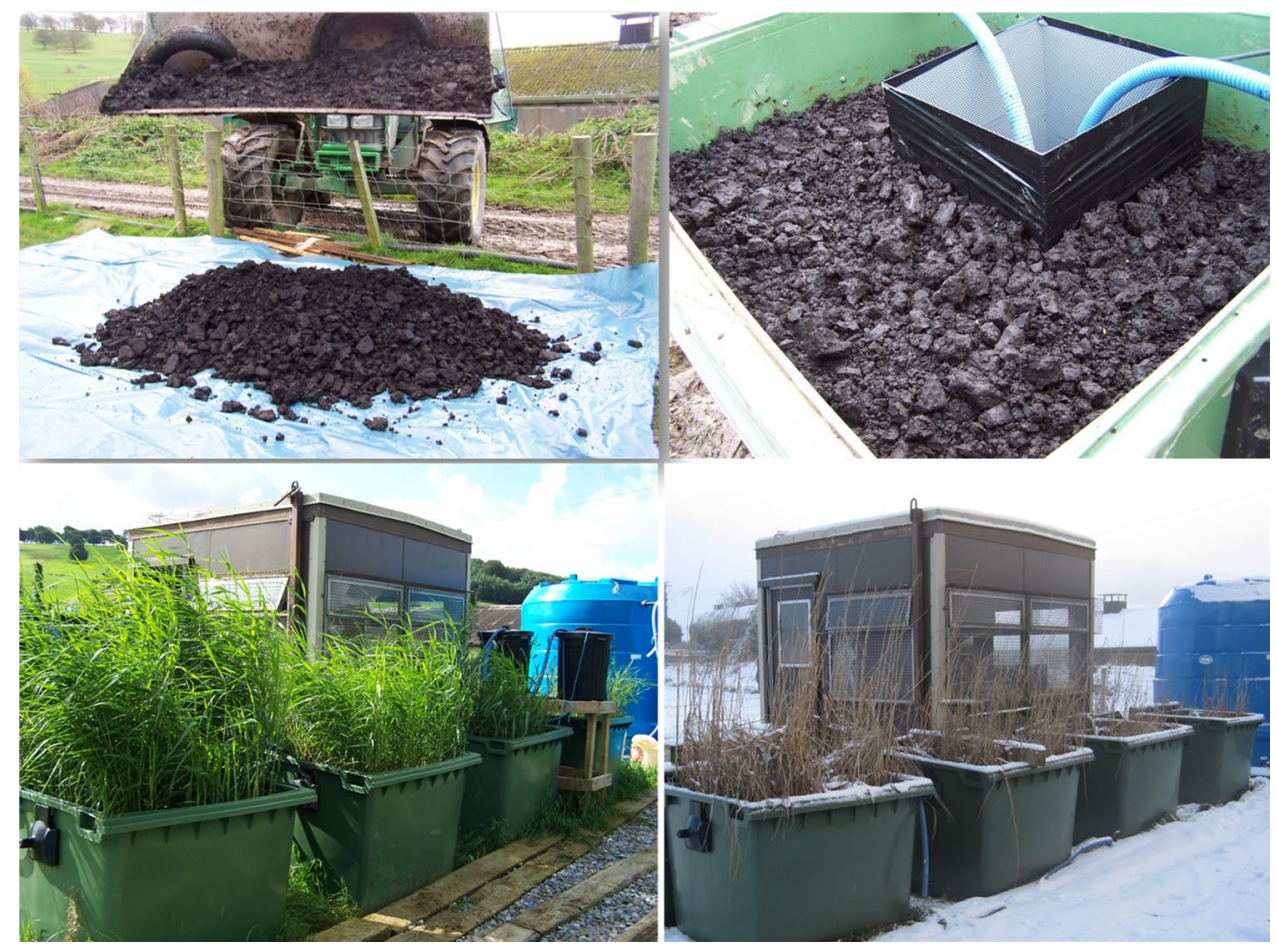

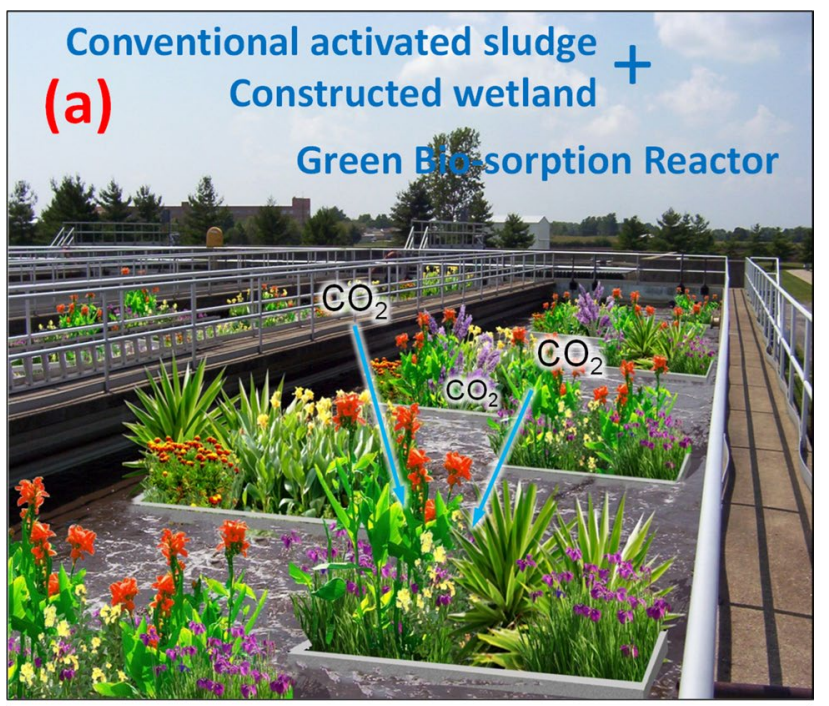

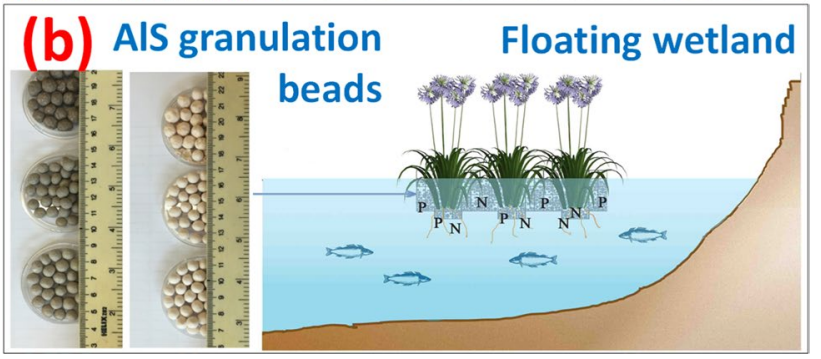

Fig. 6 AlS-based CW combination with activated sludge process (GBR) (a) and floating treatment wetland (b)

\section{Liquid WTS Used as Coagulant for Wastewater Treatment and as Conditioner for Wastewater Sludge Co-conditioning and Dewatering}

Reuse of WTS can either be in dewatered cakes or in liquid form. It has been studied and demonstrated that WTS in liquid form can be used as coagulant in wastewater industry due to its abundant content of $\mathrm{Al}^{3+}$ and $\mathrm{Fe}^{3+}$ (Table 1). For the same reason, they are also employed for wastewater sludge co-conditioning and dewatering to achieve the dual goals of polymer (conventional conditioner) saving and $\mathrm{P}$ control from the reject water.

Recently, Rebosura et al. [50] introduced Fe-WTS into the urban wastewater drainage system to effectively reduce dissolved sulphide in the sewer collection network system and the concentration of $\mathrm{P}$ in the ensuing wastewater treatment. Indeed, previous studies have demonstrated various reuse of WTS as primary coagulant [1, 3, 22, 51, 52], and as special coagulating-flocculating agents for industrial effluent purification [53], as well as for low-turbidity source water coagulation [54] to turn WTS into a value added material. $\mathrm{Hu}$ et al. [55] used liquid AlS as coagulant for pesticide immobilization in wastewater and found that the liquid AIS adsorbed P more rapidly than dewatered AlS cakes as well as having higher performance in comparison with other adsorbents. Mazari et al. [56] introduced liquid AlS into the pre-treatment process as the primary coagulant for the ultrafiltration (UF) membrane process of municipal wastewater 
treatment. Shrestha et al. [57] also used waterworks AlS in pilot sewers for the first time to replace the chemical coagulants. Kang [58] investigated the use of liquid AlS in animal farm wastewater treatment. The quantity of strong wastewater discharged by animal farms and the livestock and poultry industry is a big concern. Treatment of such strong wastewater needs significant reduction of the pollutants (such as chemical oxygen demand (COD)) in the primary stage, e.g. coagulation/flocculation and sedimentation, before biological treatment. Based on Kang's [58] trial, removal efficiencies of TSS (total suspended solids), $\mathrm{PO}_{4}{ }^{3-}$, and TOC (total organic carbon) of $87.76 \pm 2.2 \%, 96.88 \pm 2.9 \%$, and $62.14 \pm 1.8 \%$, respectively, could be obtained for animal farm wastewater treatment at the optimum initial $\mathrm{pH}$ value of 7.0 and liquid AlS dosage of $1.59 \mathrm{~g} / \mathrm{L}$. This provides AlS with an alternative option for high strength wastewater coagulation. Actually, the mechanisms behind these studies are the large specific surface area, certain pore volumes and porosity of AlS flocs [1, 19] and their oxide or hydroxide, which can perform with a strong capacity as coagulant while being adsorbent for a number of pollutants in wastewater [4].

In addition, liquid WTS can be used as "conditioner" to jointly be treated with sewage sludge. The role of the WTS that could strengthen sewage sludge conditioning lies in the strong coagulation elements of $\mathrm{Al}^{3+}$ and $\mathrm{Fe}^{3+}$ [59]. The process is to form the co-conditioning and dewatering of WTS and sewage sludge [60,61]. Yang et al. [60] conducted a study on the co-conditioning and dewatering of an Irish AlS with wastewater sludge in Dublin, Ireland and demonstrated that the AlS could improve sewage sludge dewaterability. The technical foundation was sound while simultaneous benefits were observed in savings on polymer (as conventional conditioner) dosage and control of $\mathrm{P}$ from the reject water i.e. the filtrate from the mechanical dewatering process in the sludge treatment unit in the WWTP. Taylor and Elliott [62] reported co-conditioning and dewatering of AlS with sewage sludge which reduced the amount of polymer dosage so that the total cost of sludge treatment was decreased. More recently, Ren et al. [61] demonstrated the use of a liquid AlS obtained from Graulhet waterworks in South France in co-conditioning and dewatering with sewerage sludge from a nearby WWTP. By considering the P concentration in the supernatant as well as the treatment capacity of Graulhet WWTP, the optimal mixing ratio of sewerage sludge and AlS in v/v was 1:1. Moreover, the optimal polymer (Superfloc-492HMW) dosage for the mixed sludge ratio (1:1) was $200 \mathrm{mg} / \mathrm{L}$, while the current dosage for the wasteactivated sludge in Graulhet WWTP is $2.8 \mathrm{~g} / \mathrm{L}$. An integrated cost-effective evaluation of process capabilities was considered including: AlS transport ( $3 \mathrm{~km}$ away to Graulhet WWTP), increased cakes disposal (after co-dewatering), and additional administration etc. which suggested that the coconditioning and dewatering strategy for the Graulhet water industry was practicable; theoretically the initial investment could be returned in 11 years. Therefore, a scientific investigation but also a "Circular Economy" approach was provided for the Graulhet water industry.

Although the technical aspect of co-conditioning and dewatering is promising and the benefits are sound, the only concern and difficulty in practice lies in the fact that the waterworks and the WWTP are always built separately with considerable distance between them in a city/town. This may hinder the practical application of this c-treatment strategy.

\section{Novel Use of AIS for Unpleasant Gas Purification}

AlS has recently been investigated as a raw material for hydrogen sulfide $\left(\mathrm{H}_{2} \mathrm{~S}\right)$ adsorption [62]. $\mathrm{H}_{2} \mathrm{~S}$ is one of several odorous gases from industrial effluents such as municipal wastewater treatment plants (WWTPs), landfill sites and petrochemical industries [63]. It is a poisonous, flammable, colorless gas with a characteristic odor of rotten eggs. The average odor threshold of $\mathrm{H}_{2} \mathrm{~S}$ is reported at 7 to 9 parts per billion (ppb) [64]. In the study of Ren et al. [65], dewatered AlS was used for $\mathrm{H}_{2} \mathrm{~S}$ adsorption for the first time, while various trials were performed in fixed bed columns to study the effects of $\mathrm{H}_{2} \mathrm{~S}$ flow rate and sorbent bed depth on the AlS adsorption behaviour. The breakthrough curves were simulated by adsorption models, while the mechanisms of $\mathrm{H}_{2} \mathrm{~S}$ adsorption onto the AlS were examined in great detail. The AlS adsorption capacity was determined to be $374.2 \mathrm{mg}$ of $\mathrm{H}_{2} \mathrm{~S} / \mathrm{g}$, slightly decreasing with increasing flow rate and increasing with increasing bed depth.

The study demonstrated that AlS could be a cost-effective, largely available, and efficient sorbent for $\mathrm{H}_{2} \mathrm{~S}$ removal, thus opening a novel way for $\mathrm{H}_{2} \mathrm{~S}$ removal using a "waste". In spite of the small scale lab trial, it has good potential for application in WWTPs as the unpleasant odor from wastewater treatment processes has been a long complained issue of the public and a painful concern of the wastewater treatment authority. Normally, technologies of $\mathrm{H}_{2} \mathrm{~S}$ removal from odor gas derived from WWTPs include physical/chemical (such as adsorption, chemical scrubbing) and biological approaches (biofiltration, biotrickling, activated sludge diffusion etc.) [66]. Singh et al. [67] used zinc oxide-decorated multi-wall carbon nanotubes (ZnO-MWCNTs), which was a synthesis of the carbon nanotube and zinc oxide, for a high value (98\%) of $\mathrm{H}_{2} \mathrm{~S}$ removal in a bench-scale fixed bed reactor. Sánchez-González et al. [68] investigated Mg-based metal-organic frameworks (MOFs) as a highly reversible sorbent for $\mathrm{H}_{2} \mathrm{~S}$ removal. Hervy et al. [69] reported $\mathrm{H}_{2} \mathrm{~S}$ removal by chars obtained from pyrolysis of wastes under ambient temperature in various dry gas matrices (N2, Air, Syngas). Other materials have been reported as sorbents for 
$\mathrm{H}_{2} \mathrm{~S}$ removal including fly ash, activated carbon, polymers, carbon-coated polymers, ceramics, and synthetic zeolites. The $\mathrm{H}_{2} \mathrm{~S}$ removal efficiency of these materials ranged from 8.63 to $210 \mathrm{mg} \mathrm{H}_{2} \mathrm{~S} / \mathrm{g}$ [70-72]. Obviously, compared with other materials, AlS is a easily, locally and largely available by-product with cost-effectiveness as a feature. Indeed, adsorption has the common shortcomings of material cost and the complexity of sorbent preparation and regeneration after saturation. No doubt, direct utilization of AIS for $\mathrm{H}_{2} \mathrm{~S}$ removal has attracted intensive research interest.

\section{Conclusions and Future Perspectives}

It should be noted that WTR has clear features which are obviously different with other industrial by-products. On the one hand, like with other "waste", it needs to be disposed which is associated with increased cost as well as environmental impacts, which are still worldwide issues. Historically, the simple and less thoughtful disposal routes of WTRs include discharging to a nearby natural water body, or discharging to lagoons, or sending as waste for landfilling after dewatering [73, 74]. On the other hand, it contains very useful elements of $\mathrm{Al}, \mathrm{Fe}, \mathrm{Ca}$ etc. in considerably high quantities (Table 1) which are good at adsorption and immobilization of other pollutants (Table 2). Additionally, WTS has the specific feature of being an inevitable by-product of the tap water supply service locally and largely available almost everywhere in the world. This makes it very special with unique potential to be a resource for beneficial reuse from a sustainability point of view. Thus, development of strategies for its various reuse applications is an urgent priority over the next extended period of time. Although, so far, more work is beening done, WTS is still an underrated material as landfill remains the major final disposal route in the current global situation.

From now, it is necessary to adopt/focus on $5 \mathrm{R}$ principles (Reduce, Reprocess, Reuse, Recycle and Recover) of waste management for sustainable development. It is crucial to identify viable management options for WTS, particularly where WTS can be effectively utilized in an environmentally acceptable and sustainable manner [61]. To date, there are four broad categories of beneficial WTS reuse routes. These efforts include: (1) the coagulant recovery and reuse from WTS; (2) reuse in wastewater and sewage sludge treatment processes via either the liquid or dewatered forms and jointing points of treatment processes, which are the main focuses of the current paper; (3) reuse as building/construction materials or in the manufacture of these materials in civil engineering - at least mature enough that WTSs were used as a partial replacement for clay in clay brick manufacturing [75]; and (4) land-based applications, which comprise the wide range of areas related to agricultural, forest and gardening [73].

It is worth noting that the majority of WTSs were reused in a powdery form (sorbent for pollutant removal), which was through the dried, ground and sieved processes [10]. However, the powdery forms of WTS hinder its wide engineering applications and makes it even less attractive as adsorbent since it is difficult to recover powdery WTSs (as sorbents) from the adsorption process [31]. Hence, converting raw WTS into useful value-added products via granulation is of great interest worldwide and should be further studied. It is expected that various commercial products based on WTSs should be in the market in the future, thus offering wider and wiser WTS reuse routes and further invigorate water, environmental and civil engineering.

Acknowledgements The following people are acknowledged as group members for their work on different kinds of projects towards the R\&D of beneficial reuse of WTS: Dr Yongzhe Yang, Dr Akintunde Babatunde, Dr Lordwin Kumar, Dr Maha Tony, Dr Xiaohong Zhao, Dr Yuansheng Hu, Dr Liam Doherty, Dr Ranbin Liu, Dr Lei Xu, Dr Yan Yang, Dr Wesley Awe, Ms Tongyue Wang, Mr Cheng Tang, and Miss Yi Mao.

\section{References}

1. Babatunde, A.O., Zhao, Y.Q.: Constructive approaches towards water treatment works sludge management: an international review of beneficial re-uses. Crit. Rev. Environ. Sci. Technol. 37, 129-164 (2007)

2. Dassanayake, K.B., Jayasinghe, G.Y., Surapaneni, A., Hetherington, C.: A review on alum sludge reuse with special reference to agricultural applications and future challenges. Waste Manag. 38, 321-335 (2015)

3. Ahmad, T., Ahmad, K., Alam, M.: Sustainable management of water treatment sludge through 3'R' concept. J. Clean. Prod. 124, 1-13 (2016)

4. Shen, C., Zhao, Y.Q., Li, W., Yang, Y., Liu, R., Morgen, D.: Global profile of heavy metals and semimetals adsorption using drinking water treatment residual. Chem. Eng. J. 372, 1019-1027 (2019)

5. Xu, D., Lee, L.Y., Lim, F.Y., Lyu, Z., Zhu, H., Ong, S.L., Hu, J.: Water treatment residual: a critical review of its applications on pollutant removal from stormwater runoff and future perspectives. J. Environ. Manag. 259, 109649 (2020). https://doi.org/10.1016/j. jenvman.2019.109649

6. Zhao, Y.Q., Razali, M., Babatunde, A.O., Yang, Y., Bruen, M.: Reuse of aluminium-based water treatment sludge to immobilize a wide range of phosphorus contamination: equilibrium study with different isotherm models. Sep. Sci. Technol. 42(12), 2705-2721 (2007)

7. Ackah, L., Guru, R., Peiravi, M., Mohanty, M., Ma, X., Kumar, S., Liu, J.: Characterization of southern illinois water treatment residues for sustainable applications. Sustainability 10, 1374 (2018). https://doi.org/10.3390/su10051374

8. Shakya, A.K., Bhande, R., Ghosh, P.K.: A practical approach on reuse of drinking water treatment plant residuals for fluoride removal. Environ. Technol. 2019(1588383), 1-13 (2019)

9. Muisa, N., Nhapi, I., Ruziwa, W., Manyuchi, M.M.: Utilization of alum sludge as adsorbent for phosphorus removal in municipal 
wastewater: a review. J. Water Process Eng. 35, 101187 (2020). https://doi.org/10.1016/j.jwpe.2020.101187

10. Kumar, R., Kang, C.U., Mohan, D., Khan, M.A., Lee, J.H., Lee, S.S., Jeon, B.H.: Waste sludge derived adsorbents for arsenate removal from water. Chemosphere 239, 124832 (2020)

11. Chiang, K.-Y., Chou, P.-H., Hua, C.-R., Chien, K.-L., Cheeseman, C.: Light weight bricks manufactured from water treatment sludge and rice husks. J. Hazard. Mater. 171, 76-82 (2009)

12. Ippolito, J.A., Barbarick, K.A., Elliott, H.A.: Drinking water treatment residuals : a review of recent uses. J. Environ. Qual. 2, 1-12 (2011). https://doi.org/10.2134/jeq2010.0242

13. Razali, M., Zhao, Y.Q., Bruen, M.: Effectiveness of a drinking water treatment sludge in removing different phosphorus species from aqueous solution. Sep. Purif. Technol. 55, 300-306 (2007)

14. Sales, A., De Souza, F.R., Almeida, F.R.: Mechanical properties of concrete produced with a composite of water treatment sludge and sawdust. Constr. Build. Mater. 25(6), 2793-2798 (2011)

15. Sotero-Santos, R.B., Rocha, O., Povinelli, J.: Evaluation of WTS toxicity using the Daphnia bioassay. Water Res. 39(16), 39093917 (2005)

16. Zou, J.L., Xu, G.R., Li, G.B.: Ceramsite obtained from water and wastewater sludge and its characteristics affected by $\mathrm{Fe}_{2} \mathrm{O}_{3}, \mathrm{CaO}$, and MgO. J. Hazard. Mater. 165, 995-1001 (2009)

17. Hidalgo, A.M., Murcia, M.D., Gomez, M., Gomez, E., GarciaIzquierdo, C., Solano, C.: Possible uses for sludge from drinking water treatment plants. J. Environ. Eng. 143(3), 7-16 (2017)

18. Odimegwu, T.C., Zakaria, I., Abood, M.M., Nketsiah, C.B.K., Ahmad, M.: Review on different beneficial ways of applying alum sludge in a sustainable disposal manner. Civil Eng. J.-Tehran 4(9), 2230-2241 (2018)

19. Yang, Y., Tomlinson, D., Kennedy, S., Zhao, Y.Q.: Dewatered alum sludge: a potential adsorbent for phosphorus removal. Water Sci. Technol. 54, 207-213 (2006)

20. Liu, R., Zhao, Y.Q., Sibille, C., Ren, B.: Evaluation of natural organic matter release from alum sludge reuse in wastewater treatment and its role in P adsorption. Chem. Eng. J. 302, 120-127 (2016)

21. Wang, Y., Ren, B.M., Zhao, Y.Q., English, A., Cannon, M.: A comparison of alum sludge with peat for aqueous glyphosate removal for maximizing their value for practical use. Water Sci. Technol. (2018). https://doi.org/10.2166/wst.2018.165

22. Yang, Y., Zhao, Y.Q., Babatunde, A.O., Wang, L., Ren, Y.X., Han, Y.: Characteristics and mechanisms of phosphate adsorption on dewatered alum sludge. Sep. Purif. Technol. 51, 193-200 (2006)

23. Zhao, X.H., Luo, H.L., Tao, T., Zhao, Y.Q.: Immobilization of arsenic in aqueous solution by waterworks alum sludge: prospects in China. Int. J. Environ. Stud. 72(6), 989-1001 (2015)

24. Shanmugam, S.: Granulation techniques and technologies: recent progresses. Bioimpacts 5, 55-63 (2015)

25. Li, X.Q., Cui, J., Pei, Y.S.: Granulation of drinking water treatment residuals as applicable media for phosphorus removal. J. Environ. Manag. 213, 36-46 (2018)

26. Chen, S., Chen, Y., Pei, H., Hou, Q.: Biofilm development dynamics and pollutant removal performance of ceramsite made from drinking-water treatment sludge. Water Environ. Res. 91, 616-627 (2019)

27. Wang, Y., Yang, J., Xu, H., Liu, C., Shen, Z., Hu, K.: Preparation of ceramsite based on waterworks sludge and its application as matrix in constructed wetlands. Int. J. Environ. Res. Public Health 16, 2637 (2019). https://doi.org/10.3390/ijerph16152637

28. $\mathrm{Xu}, \mathrm{G} ., \mathrm{Zou}, \mathrm{J} ., \mathrm{Li}, \mathrm{G} .:$ Ceramsite made with water and wastewater sludge and its characteristics affected by $\mathrm{SiO}_{2}$ and $\mathrm{Al}_{2} \mathrm{O}_{3}$. Environ. Sci. Technol. 42, 7417-7423 (2008)

29. Shen, C., Zhao, Y.Q., Liu, R.: Development of pellet-type adsorbent based on water treatment residual. Desalin. Water Treat. 112, 3-11 (2018). https://doi.org/10.5004/dwt.2018.21997
30. Shen, C., Zhao, Y.Q., Liu, R., Mao, Y., Morgan, D.: Adsorption of phosphorus with calcium alginate beads containing drinking water treatment residual. Water Sci. Technol. 78, 1980-1989 (2018). https://doi.org/10.2166/wst.2018.473

31. Li, X., Yu, D., Su, L., Pei, Y.: Facile method to granulate drinking water treatment residues as a potential media for phosphate removal. Colloids Surf. A Physicochem. Eng. Asp. 586, 124198 (2020). https://doi.org/10.1016/j.colsurfa.2019.124198

32. Gao, J., Guo, H., Zhang, J., Yang, R., Gao, J., Wang, G.: Preparation of sustainable non-combustion filler substrate from waterworks sludge/aluminum slag/gypsum/silica/maifan stone for phosphorus immobilization in constructed wetlands. Water Sci. Technol. 80, 153-163 (2019)

33. Zhao, Y.Q., Zhao, X.H., Babatunde, A.O.: Use of dewatered alum sludge as main substrate in treatment reed bed receiving agricultural wastewater: long-term trial. Bioresour. Technol. 100, 644-648 (2009)

34. Zhao, Y.Q., Babatunde, A.O., Hu, Y., Kumar, J.L.G., Zhao, X.H.: A two-prong approach of beneficial reuse of alum sludge in engineered wetland: first experience from Ireland. Waste Biomass Valorization 1, 227-234 (2010)

35. Hu, Y., Zhao, Y., Zhao, X., Kumar, J.L.G.: High rate nitrogen removal in an alum sludge-based intermittent aeration constructed wetland. Environ. Sci. Technol. 46, 4583-4590 (2012)

36. Hu, Y., Zhao, Y., Rymszewicz, A.: Robust biological nitrogen removal by creating multiple tides in a single bed tidal flow constructed wetland. Sci. Total Environ. 470, 1197-1204 (2014)

37. Masi, F., Rizzo, A., Bresciani, R., Martinuzzi, N., Wallace, S.D., Van Oirschot, D., Macor, F., Rossini, T., Fornaroli, R., Mezzanotte, V.: Lessons learnt from a pilot study on residual dye removal by an aerated treatment wetland. Sci. Total. Environ. 648, 144-152 (2019)

38. Nguyen, X.C., Chang, S.W., Tran, T.C.P., Nguyen, T.T.N., Hoang, T.Q., Banu, J.R., Al-Muhtaseb, A.H., La, D.D., Guo, W., Ngo, H.H., Nguyen, D.D.: Comparative study about the performance of three types of modified natural treatment systems for rice noodle wastewater. Bioresour. Technol. 282, 163-170 (2019)

39. Zhao, Y.Q., Babatunde, A.O., Hu, Y.S., Kumar, J.L.G., Zhao, X.H.: Pilot field-scale demonstration of a novel alum sludge-based constructed wetland system for enhanced wastewater treatment. Process Biochem. 46(1), 278-283 (2011)

40. Zhao, Y.Q., Babatunde, A.O., Razali, M., Harty, F.: Use of dewatered alum sludge as a substrate in reed bed treatment systems for wastewater treatment. J. Environ. Sci. Health Part A Toxic/ Hazard. Subst. Environ. Eng. 43(1), 105-110 (2008)

41. Babatunde, A.O., Zhao, Y.Q., Burke, A.M., Morris, M.A., Hanrahan, J.P.: Characterization of aluminium-based water treatment residual for potential phosphorus removal in engineered wetlands. Environ. Pollut. 157(10), 2830-2836 (2009)

42. Liu, R., Zhao, Y.Q., Zhao, J., Xu, L., Sibille, C.: A fancy ecocompatible wastewater treatment system: green bio-sorption reactor. Biores. Technol. 234, 224-232 (2017)

43. Liu, R., Zhao, Y.Q., Wang, T., Shen, C.: Long-term operation with an insight into a newly established green biosorption reactor: can it achieve " $1+1>2$ "? Biores. Technol. 255, 96-103 (2018)

44. Shen, C., Zhao, Y.Q., Liu, R., Morgan, D., Wei, T.: Enhancing wastewater remediation by drinking water treatment residualaugmented floating treatment wetlands. Sci. Total Environ. 673, 230-236 (2019)

45. Zhao, Y.Q., Collum, S., Phelan, M., Goodbody, T., Doherty, L., $\mathrm{Hu}$, Y.S.: Preliminary investigation of constructed wetland incorporating microbial fuel cell: batch and continuous flow trials. Chem. Eng. J. 229, 364-370 (2013)

46. Doherty, L., Zhao, Y., Zhao, X., Wang, W.: Nutrient and organics removal from swine slurry with simultaneous electricity 
generation in an alum sludge-based constructed wetland incorporating microbial fuel cell technology. Chem. Eng. J. 266, 74-81 (2015)

47. Xu, L., Zhao, Y.Q., Wang, X., Yu, Z.: Applying multiple biocathodes in constructed wetland-microbial fuel cell for promoting energy production and bioelectrical derived nitrification-denitrification process. Chem. Eng. J. 344, 105-113 (2018)

48. Tang, C., Zhao, Y.Q., Kang, C., Yang, Y., Morgan, D., Xu, L.: Towards concurrent pollutants removal and high energy harvesting in a pilot-scale CW-MFC: insight into the cathode conditions and electrodes connection. Chem. Eng. J. 373, 150-160 (2019)

49. Yang, Y., Zhao, Y.Q., Tang, C., Xu, L., Morgan, D., Liu, R.: Role of macrophyte species in constructed wetland-microbial fuel cell for simultaneous wastewater treatment and bioenergy generation. Chem. Eng. J. 392, 123708 (2020)

50. Rebosura Jr., M., Salehin, S., Pikaar, I., Kulandaivelu, J., Jiang, G., Keller, J., Sharma, K., Yuan, Z.: Effects of in-sewer dosing of iron-rich drinking water sludge on wastewater collection and treatment systems. Water Res 171, 115396 (2020)

51. Zhao, Y.Q.: Enhancement of alum sludge dewatering capacity by using gypsum as skeleton builder. Colloids Surf. A Physicochem. Eng. Asp. 211(2-3), 205-212 (2002)

52. Jangkorn, S., Kuhakaew, S., Theantanoo, S., Klinla-or, H., Sriwiriyarat, T.: Evaluation of reusing alum sludge for the coagulation of industrial wastewater containing mixed anionic surfactants. J. Environ. Sci. (China) 23(4), 587-594 (2011)

53. Nair, A.T., Ahammed, M.M.: Water treatment sludge for phosphate removal from the effluent of UASB reactor treating municipal wastewater. Process Saf. Environ. Prot. 94, 105-112 (2015)

54. Xu, Y., Chen, T., Xu, R., He, L., Cui, F.: Impact of recycling alum sludge on coagulation of low-turbidity source waters. Desalin. Water Treat. 57(15), 6732-6739 (2015)

55. Hu, Y.S., Zhao, Y.Q., Sorohan, B.: Removal of glyphosate from aqueous environment by adsorption using water industrial residual. Desalination 271(1-3), 150-156 (2011)

56. Mazari, L., Abdessemed, D., Szymczyk, A., Trari, M.: Assessment of coagulation-ultrafiltration performance for the treatment of primary wastewater using alum sludge. Water Environ. J. 32(4), 621-629 (2018)

57. Shrestha, S., Kulandaivelu, J., Sharma, K., Jiang, G., Yuan, Z.: Effects of dosing iron- and alum-containing waterworks sludge on sulfide and phosphate removal in a pilot sewer. Chem. Eng. J. 387, 124073 (2020). https://doi.org/10.1016/j.cej.2020.124073

58. Kang, C.: Reuse of aluminum-based water treatment sludge as coagulant for animal farm wastewater treatment, MEngSc thesis. University College Dublin, Dublin (2017)

59. Lai, J.Y., Liu, J.C.: Co-conditioning and dewatering of alum sludge and waste activated sludge. Water Sci. Technol. 50(9), 41-48 (2004)

60. Yang, Y., Zhao, Y.Q., Babatunde, A.O., Kearney, P.: Co-conditioning of the anaerobic digested sludge of a municipal wastewater treatment plant with alum sludge: benefit of phosphorus reduction in reject water. Water Environ. Res. 79(13), 2468-2476 (2007)

61. Ren, B., Lyczko, N., Zhao, Y., Nzihou, A.: Integrating alum sludge with waste-activated sludge in co-conditioning and dewatering: a case study of a city in south France. Environ. Sci. Pollut. Res. 27, 14863-14871 (2020). https://doi.org/10.1007/s11356-020-08056 $-0$
62. Taylor, M., Elliott, H.A.: Influence of water treatment residuals on dewaterability of wastewater biosolids. Water Sci. Technol. 67(1), 180-186 (2012)

63. Bamdad, H., Hawboldt, K., MacQuarrie, S.: A review on common adsorbents for acid gases removal: focus on biochar. Renew. Sustain. Energy Rev. 81, 1705-1720 (2018)

64. Wu, H., Zhu, Y., Bian, S., Ko, J.H., Li, S.F.Y., Xu, Q.: H2S adsorption by municipal solid waste incineration (MSWI) fly ash with heavy metals immobilization. Chemosphere 195, 40-47 (2018)

65. Ren, B., Lyczko, N., Zhao, Y.Q., Nzihou, A.: Alum sludge as an efficient sorbent for hydrogen sulfide removal: experimental, mechanisms and modeling studies. Chemosphere 248, 126010 (2020). https://doi.org/10.1016/j.chemosphere.2020.126010

66. Ren, B., Zhao, Y.Q., Lyczko, N., Nzihou, A.: Current status and outlook of odor removal technologies in wastewater treatment plant. Waste Biomass Valorization 10(6), 1443-1458 (2019)

67. Singh, A., Pandey, V., Bagai, R., Kumar, M., Christopher, J., Kapur, G.S.: ZnO-decorated MWCNTs as solvent free nanoscrubber for efficient $\mathrm{H}_{2} \mathrm{~S}$ removal. Mater. Lett. 234, 172-174 (2019)

68. Sánchez-González, E., Mileo, P.G.M., Sagastuy-Breña, M., Álvarez, J.R., Reynolds, J.E., Villarreal, A., Gutiérrez-Alejandre, A., Ramírez, J., Balmaseda, J., González-Zamora, E., Maurin, G., Humphrey, S.M., Ibarra, I.A.: Highly reversible sorption of $\mathrm{H}_{2} \mathrm{~S}$ and $\mathrm{CO}_{2}$ by an environmentally friendly Mg-based MOF. J. Mater. Chem. A 6(35), 16900-16909 (2018)

69. Hervy, M., Pham Minh, D., Gérente, C., Weiss-Hortala, E., Nzihou, A., Villot, A., Le Coq, L.: $\mathrm{H}_{2} \mathrm{~S}$ removal from syngas using wastes pyrolysis chars. Chem. Eng. J. 334, 2179-2189 (2018)

70. Sharma, S., Verma, A.S.: A theoretical study of $\mathrm{H}_{2} \mathrm{~S}$ adsorption on graphene doped with B, Al and Ga. Phys. B 427, 12-16 (2013)

71. Sitthikhankaew, R., Chadwick, D., Assabumrungrat, S., Laosiripojana, N.: Effects of humidity, $\mathrm{O}_{2}$, and $\mathrm{CO}_{2}$ on $\mathrm{H}_{2} \mathrm{~S}$ adsorption onto upgraded and $\mathrm{KOH}$ impregnated activated carbons. Fuel Process. Technol. 124, 249-257 (2014)

72. Wang, J., Wang, L., Fan, H., Wang, H., Hu, Y., Wang, Z.: Highly porous copper oxide sorbent for $\mathrm{H}_{2} \mathrm{~S}$ capture at ambient temperature. Fuel 209, 329-338 (2017)

73. Zhao, Y.Q., Liu, R., Awe, W., Yang, Y., Shen, C.: Acceptability of land application of alum-based water treatment residuals-an explicit and comprehensive review. Chem. Eng. J. 353, 717-726 (2018)

74. Turner, T., Wheeler, R., Stone, A., Oliver, I.: Potential alternative reuse pathways for water treatment residuals: remaining barriers and questions - a review. Water Air Soil Pollut. 230, 227 (2019). https://doi.org/10.1007/s11270-019-4272-0

75. Zhao, Y.Q., Ren, B., O'Brien, A., O’Toole, S.: Using alum sludge for clay brick: an Irish investigation. Int. J. Environ. Stud. 73(5), 719-730 (2016) 


\section{Affiliations}

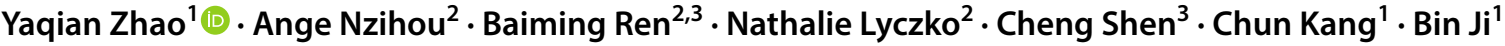

$1 \quad$ State Key Laboratory of Eco-Hydraulics in Northwest Arid Region, Xi'an University of Technology, Xi' an 710048,

People's Republic of China

2 UMR-5302, Université de Toulouse, IMT Mines Albi,

RAPSODEE CNRS, Campus Jarlard, 81013 Albi Cedex 09,

France
Centre for Water Resources Research, School of Civil Engineering, University College Dublin, Belfield, Dublin 4, Ireland 